\title{
Water-reduction potential of air-cooled condensers in coal power plants in India and anticipated trade-offs
}

\author{
Roshna Nazar ${ }^{1}$ (D) \\ Received: 19 June 2019 / Accepted: 1 June 2020 / Published online: 12 June 2020 \\ (c) The Author(s) 2020
}

\begin{abstract}
Wet cooling towers (WCT) are widely used to reject the unutilized heat in coal thermal power plants (TPPs). But this comes at the cost of excessive water consumption. Adoption of air-cooled condensers (ACC), also known as dry cooling systems, in all proposed Indian TPPs would reduce their water consumption by $26 \%$ in 2030 . However, power producers are reluctant to install ACC due to technical and economic disadvantages such as high capital investment and land footprint. This study evaluates the major challenges in implementing ACC by quantifying them in terms of cost of electricity generation. Critical parameters of WCT and ACC, such as water and auxiliary consumption, are also estimated at varying ambient air conditions. The study shows that cost of electricity generation in TPPs with ACC would increase by $0.26-0.30 \mathrm{INR} / \mathrm{kWh}(0.37-0.42$ US cents $/ \mathrm{kWh}$ ) compared to those TPPs with WCT. Despite this, installation of ACC would still be economically viable for those TPPs that are susceptible to at least 1 month of shutdown annually due to water shortages. On an average, Indian plants that are located at high water-stressed regions operate 1.5 months lesser than those at low and medium water-stressed regions. Such TPPs would see an increase in cost of electricity generation by $0.17 \mathrm{INR} / \mathrm{kWh}(0.24 \mathrm{US}$ cents/kWh $)$ compared to TPPs with ACC.
\end{abstract}

Keywords Coal thermal power plant - Water consumption $\cdot$ Air-cooled condenser $\cdot$ Wet cooling systems $\cdot$ Cost of electricity generation $\cdot$ Water consumption norms for coal thermal power plant in India

\section{Introduction}

Coal thermal power plants (TPPs) in India will continue their dominance in the energy mix at least till 2030 (Carpenter 2015; CEA 2018; Srinivasan et al. 2018). However, this comes at a cost of extreme water consumption of 4600 million $\mathrm{m}^{3}$ annually (CSE 2014; Greenpeace International 2015). This is equivalent to the annual water consumption of a population of 500 million people for their basic needs (estimated from the specific water consumption of $25 \mathrm{~L}$ per capita per day) (CSE 2014; Greenpeace International 2015). The current water consumption in Indian coal TPPs

Electronic supplementary material The online version of this article (https://doi.org/10.1007/s13201-020-01246-8) contains supplementary material, which is available to authorized users.

Roshna Nazar

roshna@cstep.in

1 Center for Study of Science, Technology and Policy, \#18\&19, 10th Cross, Mayura Street, Papanna Layout, Nagashettyhalli, RMV II Stage, Bengaluru, Karnataka, India is around 1100 million $\mathrm{m}^{3}$ higher than the water consumed in Chinese coal power plants, whose overall installed capacity is 2.5 times higher than India's (Greenpeace International 2015; Xinxin et al. 2017). The reduced water consumption in Chinese TPPs is mainly attributed to their optimal use of water for coal-dust suppressing, ash handling, and cooling (Carpenter 2015; Gao et al. 2018). The specific water consumption of Indian coal TPPs $\left(5-7 \mathrm{~m}^{3} / \mathrm{MWh}\right)$ is much higher than the global averages as well $\left(1.3-2.5 \mathrm{~m}^{3} / \mathrm{MWh}\right)$.

Currently, around $36 \%$ of the coal TPPs in India are located in highly water-stressed regions. Frequent interruptions in electricity generation due to water shortages are common in these coal TPPs. Hence, the plant load factor (PLF) of these TPPs is nearly $21 \%$ lesser than those situated at low and medium water-stressed regions (Tianyi et al. 2018). World Resource Institute reported that, between 2013 and 2016, 14 of India's 20 large coal TPPs had shutdowns for about 1-9 months annually due to water shortages (Tianyi et al. 2018; CEEW 2017). Plants located in less water-stressed regions had also experienced water shortages in recent years due to change in rainfall patterns (Burton

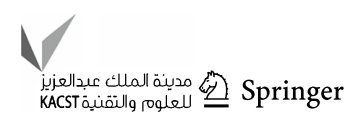


and Fernandes 2016; Burton 2018). This had resulted in an annual generation loss of $14 \mathrm{TWh}$ (TeraWatt hours), equivalent to a revenue loss of INR 56 billion (USD 0.8 billion) [estimated at a rate of INR $4 / \mathrm{kWh}$ (US cents $5.71 /$ kWh-based on dollar to Indian rupee rate in 2018)] in 2017 (Tianyi et al. 2018).

At present, India is grappled with serious water scarcity issues and around 163 million people do not even have access to clean water (WaterAid 2018). By 2030, the country's overall water demand is projected to be twice the current supply (NITI Aayog 2018), and nearly $40 \%$ of the population (approximately 600 million) will not have access to drinking water (NITI Aayog 2018). During the same time period, electricity generation from coal TPPs is expected to grow to twice its current value (Srinivasan et al. 2018). This will result in further increase in water demand from power sector.

Considering the gravity of the situation, the Ministry of Environment, Forest and Climate Change (MoEFCC), Government of India, has issued a notification on water consumption standards to minimize water consumption in coal TPPs. As per the notification, coal TPPs have to reduce their water consumption to 3-3.5 $\mathrm{m}^{3} / \mathrm{MWh}$ (MoEFCC 2015). Adoption of new technologies with low water consumption, at least in newly planned TPPs, is desirable for minimizing the water consumption and continuous power generation.

Cooling systems in coal TPPs consume the highest amount of water among all operations (approximately 86-92\% of total water consumption) (Bhattacharya 2016; Muthuraman 2016). Therefore, the introduction of new technologies in cooling operations will reduce the overall water consumption significantly. The cooling systems widely used in Indian TPPs are Once-Through Cooling (OTC) and Wet Cooling Towers (WCT) (Tenaska Trailblazer Partners, LLC 2012). As per the new water consumption norms, OTCs need to be replaced with closed cooling towers by 2022 because of their high water withdrawal rates (MoEFCC 2015).

WCT is the most popular cooling system in India. It works on the principle of evaporative cooling. Hot water from the condenser is distributed from top of the tower via spray nozzles and gets into contact with atmospheric air (Fig. 2). During this contact, small volumes of water evaporate to the air by absorbing heat from the remaining water. Atmospheric air is circulated into the tower either by natural convection or fans (Fig. 1) (Dutta 2007). The water is circulated until its temperature is lowered to the desired inlet temperature of water given to the condenser.

The performance of the WCT depends on the wet bulb temperature of ambient air, as it works based on evaporative cooling. Wet bulb temperature is the lowest temperature that the cold water can achieve via evaporative cooling. It represents how much water vapor the atmosphere can hold at the current pressure and temperature and is related to the relative humidity of air. Lower the ambient air humidity, more water it can hold, thereby easing the cooling process (Perry and Green 2008).

Of late, air-cooled condensers (ACCs) have been receiving a lot of interest globally as their operations do not involve water consumption. Many countries, especially China, have promoted ACCs over the past few years and have already installed them in over $18 \%$ of their total coal power plants (Olsson 2015; Xinxin et al. 2017). ACC operates similar to a finned-tube heat exchanger, where steam is passed through the tube side and air flows through the shell side (Dutta 2009). The steam from the turbine outlet is directly given to the tube side of ACC, thereby avoiding the need of a separate condenser as in TPP with WCT (Fig. 2). The steam condenses by giving out latent heat to the air sucked in through fans (Fig. 1). The water thus formed is recirculated to the boiler. An advantage of using ACCs is their flexibility to be installed in any plot-plan arrangement as it is not necessary to have them near the water source or reservoir. Moreover, the quantity of water needed to be processed in the water treatment plant and the amount of water-treatment chemicals required will reduce with ACC as compared to WCT (Manish and Bartaria 2013). The performance of ACC depends on ambient temperature of air rather than wet bulb temperature as it operates like a heat exchanger. Therefore, lower the ambient air temperature, higher will be the heat transfer rate, thereby easing the cooling operation.

Even though water consumption will reduce significantly with ACC, only $1 \%$ of the current coal TPPs have it installed in India (Tianyi et al. 2018). Higher auxiliary power consumption, land footprint, capital cost, and adverse impact on plant efficiency are the major impediments toward its wide adoption. However, considering the frequent outages in electricity generation due to water shortages, it is desirable to analyze the techno-economic viability of ACC in Indian coal TPPs. Adoption of ACC is possible in these TPPs as they are yet to get environmental clearance for TPP construction. Nearly $28 \mathrm{GW}$ of the coal TPPs are in announced or pre-permit development stage, which will be commissioned during 2027-2030 (CoalSwarm 2016).

Studies on implications of ACC in TPPs are sparse in the Indian context. A few studies conducted in other countries analyzed the water usage, cost, and performance of plants with various cooling systems (EPRI and California Energy Commission 2002; Zhai and Rubin 2016). However, a techno-economic feasibility analysis on implementation of ACC in coal power plants in India has not been conducted yet. None of the earlier studies covered the economics of installing ACC in new plants that are susceptible to shutdowns due to water shortages.

The current study evaluates the techno-economic feasibility of installing ACC in proposed coal power plants in India. The cost of electricity generation with ACC and 
(a)

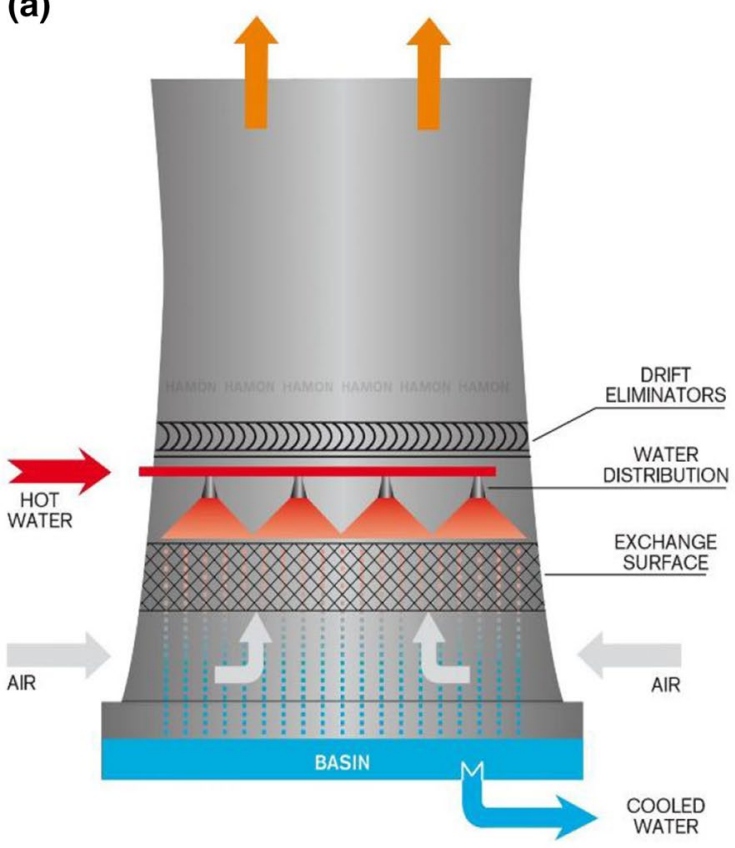

(b)

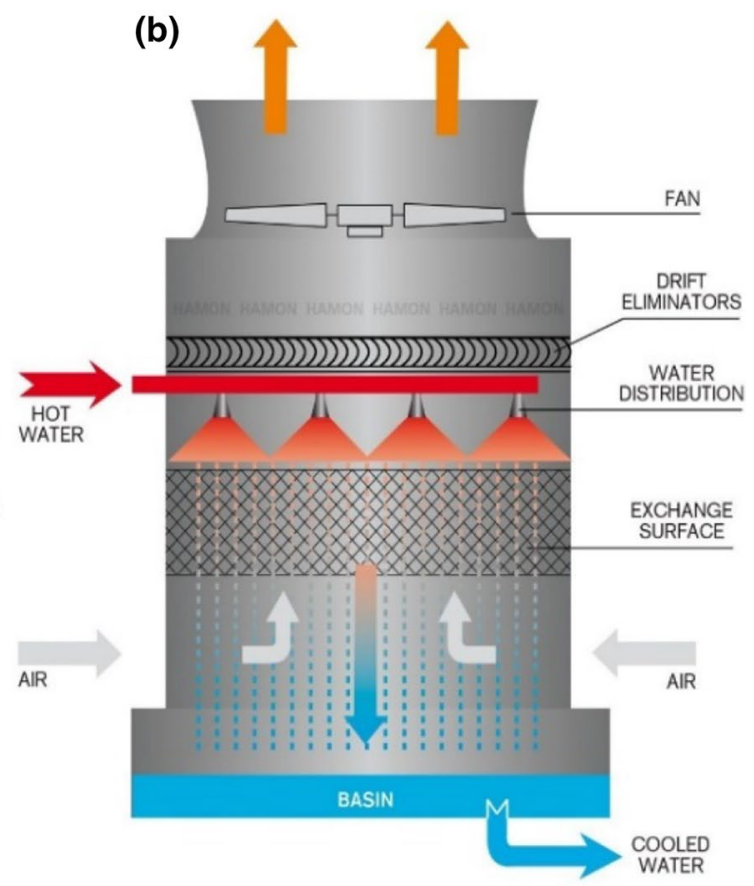

(c)

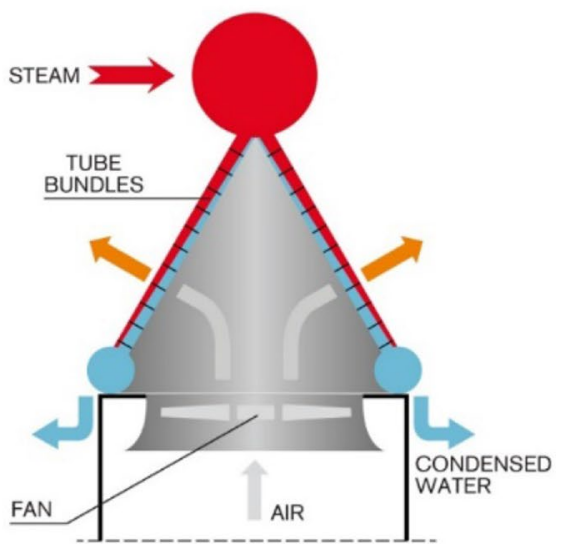

Fig. 1 a Wet natural draft cooling tower, $\mathbf{b}$ wet induced draft cooling tower, $\mathbf{c}$ air-cooled condenser (Hamon group 2018)

WCT are evaluated for a model plant. The overall implications of ACC on water and auxiliary consumption are also evaluated and compared with WCT. OTC is not considered in this analysis as such systems are being replaced with WCTs.

The current study focuses on estimating the following aspects for a TPP:

(1) Evaluation of critical parameters of cooling systems for ACC and WCT, such as:

- Auxiliary power consumption

- Water consumption

(2) Estimation of cost of electricity generation for TPPs with ACC and WCT cooling systems
(3) Assessment of overall implications of ACC in all proposed plants

(4) Sensitivity analysis of cost of electricity generation, by:

- Varying shutdown periods due to water shortages

- Analyzing the impact of local ambient conditions on performance of cooling systems

\section{Methodology}

As mentioned in the Introduction section, nearly $28 \mathrm{GW}$ of coal-based power plants are in pre-permit or allotted stage. A model power plant representing a new coal TPP of unit capacity $660 \mathrm{MW}$, plant efficiency $38 \%$ (super critical), and PLF of 75\% is considered for the analysis (Nexant, Inc 2014; 


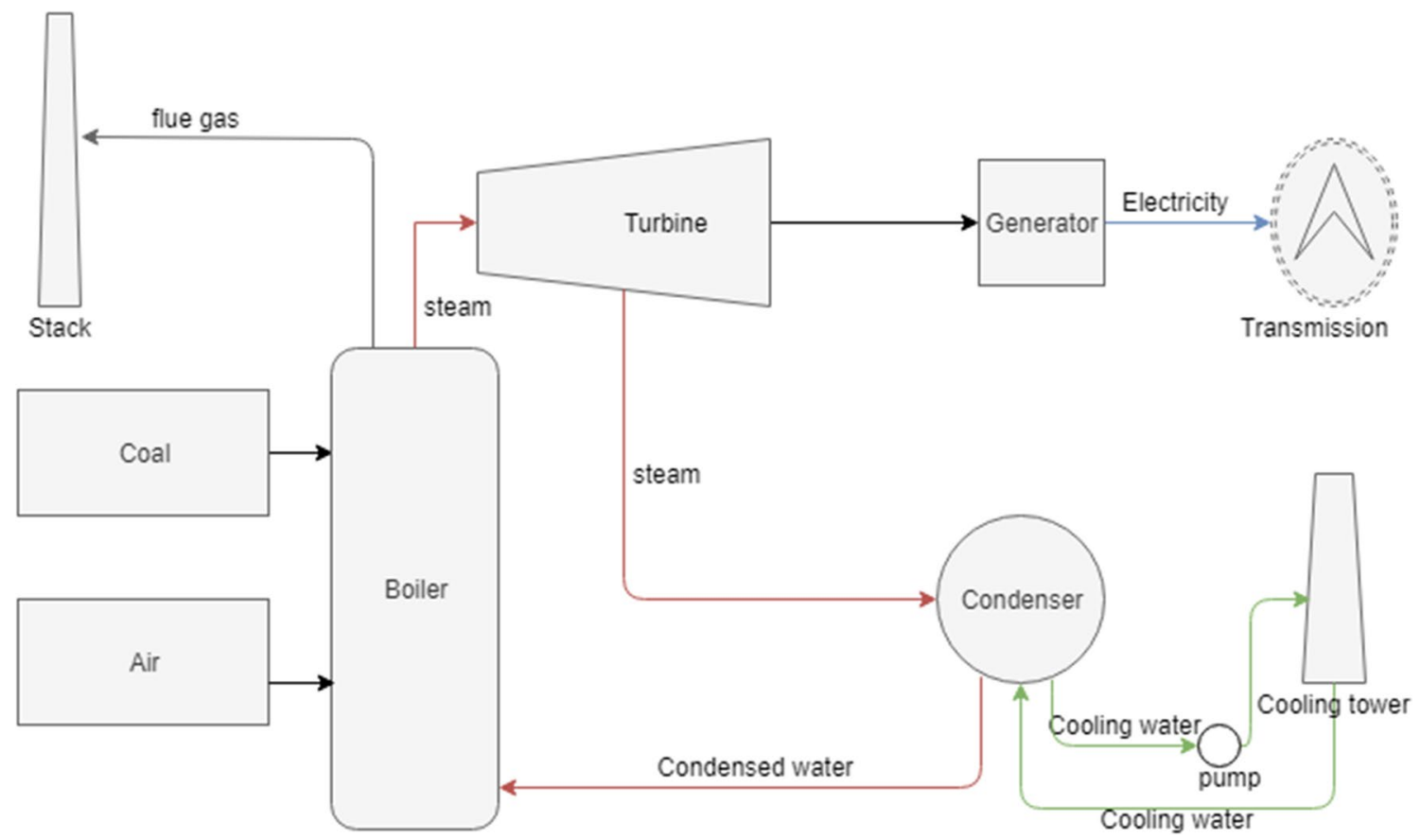

Fig. 2 Schematic diagram of TPP with WCT

CEA 2015). To evaluate the critical parameters of cooling systems, the ambient air conditions at Nellore district (in the state of Andhra Pradesh, India) is considered. This district has the highest planned installed capacity between 2027 and 2030 (CoalSwarm 2016). The annual average dry bulb temperature at Nellore is $30{ }^{\circ} \mathrm{C}$ and relative humidity is $70 \%$ (Timeanddate.com 2018). The wet bulb temperature at this condition, estimated using a psychrometric chart, is $27{ }^{\circ} \mathrm{C}$ (Narayanan 2013). Using the aforementioned plant and location specific data, critical parameters of cooling systems are estimated. The methodology section is divided into two separate sections: (1) methodology for estimating critical parameters of WCT and (2) methodology for estimating critical parameters of ACC.

\section{Methodology for estimating critical parameters of WCT}

\section{Estimation of water consumption}

Water is consumed by WCT to compensate for the circulation water lost during the cooling process. Water loss is mainly due to evaporation, drift, and blow-down. Evaporation loss occurs as the cooling process is driven by mass transfer from circulating water to air. Drift loss is mainly due to the entrainment of water along with air. This is typically around $0.02 \%$ of the circulation water flow (Perry and Green 2008). To reduce the drift loss, drift eliminators are deployed in cooling towers (Paharpur 2018). The blow-down operation in WCTs discards some amount of the circulating water to reduce the solid concentration. It is calculated based on the number of water recirculation cycles [cycles of concentration, $(\mathrm{CoC})$ ] possible with limited scale formation in WCT. It typically ranges from 2 to $7 \mathrm{CoC}$, depending on the quality of water.

The inlet and outlet water temperature of WCT is fixed at $42{ }^{\circ} \mathrm{C}$ and $30{ }^{\circ} \mathrm{C}$, respectively (Abbi 2011). The equations used for calculating makeup water consumption are taken from Perry's Chemical Engineer's Handbook and is given by, (Perry and Green 2008)

$V_{\text {makeup }}=V_{\mathrm{e}}+V_{\mathrm{d}}+V_{\mathrm{b}}$

where $V_{\text {makeup }}$ is the volume of total makeup water required $\left(\frac{\mathrm{m}^{3}}{\mathrm{~h}}\right) ; V_{\mathrm{e}}$ is the evaporative loss $\left(\frac{\mathrm{m}^{3}}{\mathrm{~h}}\right) ; V_{\mathrm{d}}$ is the drift loss $\left(\frac{\mathrm{m}^{3}}{\mathrm{~h}}\right)$ and $V_{\mathrm{b}}$ is the blow-down loss $\left(\frac{\mathrm{m}^{3}}{\mathrm{~h}}\right)$.

$V_{\mathrm{e}}=0.00085 \times V_{\mathrm{w}} \times\left(T_{\mathrm{ctw}_{1}}-T_{\mathrm{ctw}_{2}}\right)$

where $V_{\mathrm{w}}$ is the volume of circulating water $\left(\frac{\mathrm{m}^{3}}{\mathrm{~h}}\right) ; T_{\mathrm{ctw}_{1}}$ is the temperature of inlet water from WCT $\left({ }^{\circ} \mathrm{F}\right)$ and $T_{\mathrm{ctw}_{2}}$ is the temperature of outlet water from WCT $\left({ }^{\circ} \mathrm{F}\right) ; 0.00085$ is the evaporation constant, a reasonable rule-of-thumb value. However, evaporation constant will vary by season and climate (Perry and Green 2008).

$V_{\mathrm{d}}=0.002 \times V_{\mathrm{w}}$ 
$V_{\mathrm{b}}=\frac{V_{\mathrm{e}}-(c-1) \times V_{\mathrm{d}}}{c-1}$

where $c$ is the cycles of concentration.

Therefore, makeup water required in the cooling tower per MWh electricity generation $V_{\mathrm{CT}}\left(\frac{\mathrm{m}^{3}}{\mathrm{MWh}}\right)$,

$V_{\mathrm{CT}}=\frac{V_{\text {makeup }}}{\text { Gen }}$

where Gen is the gross electricity generation (MWh), given as

Gen $=$ Installed capacity $($ MW $) \times$ PLF $\times 24 \times 365$

\section{Estimation of auxiliary power consumption}

Auxiliary power consumption of WCT mainly depends on type of drafts used for circulating air. In natural draft tower, electricity is consumed only to pump water to desired height. On the other hand, in mechanical draft towers, electricity is also consumed to operate fans. The auxiliary consumption of pumps mainly depends on the required head and circulating water flow rate. The auxiliary power consumption to pump water to the desired height is given by (Perry and Green 2008; Amit et al. 2015).

$P_{\mathrm{p}}=\frac{M_{\mathrm{w}} \times h \times g}{P_{\text {eff }}}$

where $M_{\mathrm{w}}$ is the mass of the circulating water $\left(\frac{\mathrm{kg}}{\mathrm{h}}\right) ; P_{\mathrm{p}}$ is the pump power $(\mathrm{kW}) ; h$ is the pump head $(\mathrm{m})$ and is considered as $9 \mathrm{~m}$, and $P_{\text {eff }}$ is the pump efficiency in percentage and is taken as $85 \%$. The percentage of total electricity consumed during the pumping operation in WCT is given as

$A \mathrm{ux}_{\mathrm{pump}}=\frac{P_{\mathrm{p}}}{\mathrm{Gen}} \times 100$
The fan power required in wet cooling towers with mechanical drafts depends on the volumetric flow rate of air, which is directly linked to the circulating water flow rate and ambient air conditions such as relative humidity, density and temperature. The equation to estimate the fan power is given by (Perry and Green 2008),

$P_{\mathrm{f}}=\frac{G}{8000}$

where $G$ is the volumetric flow rate of air in actual cubic feet per minute (acfm), and 8000 is the volumetric flow rate in acfm that $1 \mathrm{hp}$ can draw. The detailed methodology to estimate the volumetric flow rate is provided in the Appendix.

Therefore, the percentage of total electricity consumed for circulating air in mechanical draft WCT is given by,

$\operatorname{Aux}_{\text {fan }}=\frac{P_{\mathrm{f}}}{\text { Gen }} \times 100$

\section{Estimation of cost of electricity generation}

The auxiliary power consumption and water consumption for WCT are quantified in terms of the cost of electricity generation in the model plant following the tariff guidelines (2014-2019) notified by Central Electricity Regulatory Commission (CERC), Government of India (CERC 2014; Srinivasan et al. 2018). Inputs such as base plant's capital cost, variable cost (coal cost) and operation and maintenance cost were taken from Srinivasan et al. 2018. Other additional inputs for estimating cost of electricity with WCT are provided in Table 1 (EPRI and California Energy Commission 2002; CERC 2014; Bhattacharya 2016).

Table 1 Inputs for estimating cost of electricity generation with WCT

\begin{tabular}{lll}
\hline Parameter & Natural draft & Mechanical draft \\
\hline Capital cost of WCT (INR million/MW) (USD/MW) & $1.7(24,285)$ & $0.75(10,714)$ \\
Land required $\left(\mathrm{m}^{2} / \mathrm{MW}\right)$ & 12 & $172(205)$ \\
Land cost $\left(\mathrm{INR} / \mathrm{m}^{2}\right)\left(\mathrm{US}\right.$ cents/yard $\left.{ }^{2}\right)$ & $0.7(10,000)$ \\
Operational and maintenance cost for cooling system (O\&M) (INR million/MW) (USD/MW) & 38 & $0.8(11,428)$ \\
Base plant efficiency (\%) & 5.25 \\
Auxiliary power consumption of base plant excluding cooling tower for $660 \mathrm{MW}(\%$ total generation) & 2.5 \\
Water consumption of base plant excluding cooling tower for $660 \mathrm{MW}\left(\mathrm{m}^{3} / \mathrm{MWh}\right)$ & $7(10)$ \\
Cost of water per liter (INR/m $\left.{ }^{3}\right)\left(\mathrm{US}\right.$ cents $\left./ \mathrm{m}^{3}\right)$ & 0 \\
Degradation in plant efficiency with WCT $(\%)$ & 0
\end{tabular}




\section{Methodology for estimating critical parameters of ACC}

\section{Estimation of water and auxiliary power consumption}

The water consumed during cooling operations in ACC is zero as there is no direct exposure of water with ambient air.

Auxiliary power consumption of the ACC fan depends on the volumetric flow rate of air required for the desired cooling and pressure drop across the tubes. A large volume of air is required for ACCs to condense steam, as the heat transfer coefficient for air is 30-50 times lesser than water (Engineering ToolBox 2003). Therefore, the auxiliary power consumption of ACC will be higher than WCT. The required fan power is estimated from the air flow rate and air pressure drop, using the equation (GPSA; Perry and Green 2008)

$p_{\mathrm{f}}=\frac{\Delta P \times G}{f_{\mathrm{eff}}}$

where $\Delta P$ is the total pressure drop (including velocity pressure drop and static pressure drop) and $f_{\text {eff }}$ is the fan efficiency, considered as $85 \%$. The detailed methodology to estimate the velocity pressure drop and the static pressure drop are provided in the Appendix.

Subsequently, the percentage of total electricity consumed for circulating air in ACC is estimated using Eq. (10).

\section{Estimation of cost of electricity generation}

The auxiliary power consumption and water consumption for ACC are quantified in terms of cost of electricity generation using the guidelines notified by CERC (CERC 2014; Srinivasan et al. 2018). The additional inputs for

Table 2 Inputs for estimating cost of electricity generation with ACCs

\begin{tabular}{ll}
\hline Parameter & ACC \\
\hline Capital cost of cooling systems (INR million/MW) & 2.5 \\
Land required $\left(\mathrm{m}^{2} / \mathrm{MW}\right)$ & 27 \\
Degradation in overall plant efficiency (\%) & 3 \\
Operational and maintenance (O\&M) cost (INR million/MW) & 1 \\
\hline
\end{tabular}

estimating tariff are provided in Table 2 (Bhattacharya 2016).

Based on the inputs provided in Table 2, the overall plant efficiency would decrease by $3 \%$ with ACC (Bhattacharya 2016). This implies that the coal consumption will increase by $4-6 \%$. The land footprint of ACC is 1.5-2.25 times higher than that of WCT (Bhattacharya 2016). The capital cost is also higher for ACC (Bhattacharya 2016). It is around 1.5 times higher than natural draft systems and 3 times higher than mechanical draft systems (Zhai and Rubin 2010; Bhattacharya 2016).

\section{Sensitivity analysis}

As mentioned in the introductory section, the performance of a cooling system depends on ambient air conditions. Ambient air conditions at a few power plant clusters are used to analyze the variation in water consumption, auxiliary power consumption, and resultant cost of electricity generation with location. Ambient conditions at power plant cluster regions such as Talcher (Odisha state), Korba (Chhattisgarh state), Singareni (Telangana state), Singrauli (Madhya Pradesh state), and Kutch (Gujarat state) were collated (CEA 2015). The variation in water and auxiliary power consumption and resultant cost of electricity generation are evaluated with varying ambient air conditions. The ambient temperature and humidity at these power plant clusters are tabulated (Table 3) (World Weather Online 2018).

A sensitivity analysis of cost of electricity generation with varying anticipated plant shutdown periods due to water shortages is also performed. Shutdown periods are varied from 1 to 6 months.

\section{Results}

This section is divided into four parts: (1) water consumption, (2) auxiliary power consumption, (3) cost of electricity, and (4) sensitivity analysis for cost of electricity generation.

Table 3 Ambient conditions at power plant clusters in India

\begin{tabular}{|c|c|c|c|c|c|}
\hline Region & Talcher & Korba & Singareni & Singrauli & Kutch \\
\hline $\begin{array}{l}\text { Annual average temperature }\left({ }^{\circ} \mathrm{C}\right) \text { and corresponding humid- } \\
\text { ity observed }(\%)\end{array}$ & $32^{\circ} \mathrm{C}$ and $40 \%$ & $32{ }^{\circ} \mathrm{C}$ and $20 \%$ & $32{ }^{\circ} \mathrm{C}$ and $75 \%$ & $29^{\circ} \mathrm{C}$ and $80 \%$ & $29^{\circ} \mathrm{C}$ and $73 \%$ \\
\hline $\begin{array}{l}\text { Maximum temperature }\left({ }^{\circ} \mathrm{C}\right) \text { and corresponding humidity } \\
\text { observed }(\%)\end{array}$ & $42^{\circ} \mathrm{C}$ and $50 \%$ & $43^{\circ} \mathrm{C}$ and $26 \%$ & $41{ }^{\circ} \mathrm{C}$ and $45 \%$ & $43^{\circ} \mathrm{C}$ and $21 \%$ & $40^{\circ} \mathrm{C}$ and $38 \%$ \\
\hline $\begin{array}{l}\text { Minimum temperature }\left({ }^{\circ} \mathrm{C}\right) \text { and corresponding humidity } \\
\text { observed }(\%)\end{array}$ & $15^{\circ} \mathrm{C}$ and $39 \%$ & $13^{\circ} \mathrm{C}$ and $31 \%$ & $19^{\circ} \mathrm{C}$ and $47 \%$ & $12{ }^{\circ} \mathrm{C}$ and $40 \%$ & $20^{\circ} \mathrm{C}$ and $39 \%$ \\
\hline
\end{tabular}




\section{Water consumption}

The specific water consumption of WCT in a $660 \mathrm{MW}$ new coal TPP is around $5.05 \mathrm{~m}^{3} / \mathrm{MWh}$ and $2.96 \mathrm{~m}^{3} / \mathrm{MWh}$ for $\mathrm{CoC}$ of 2 and 7, respectively. The variation of the total makeup water consumption with $\mathrm{CoC}$ is shown in Fig. 3. The graph shows that the water consumption of WCT has a strong dependence on $\mathrm{CoC}$ and, in turn, on water quality. Therefore, improving the quality of circulating water in WCT could reduce the water consumption significantly. However, after 5 cycles, water consumption does not decrease significantly.

Installation of drift eliminators could also reduce water consumption. With drift eliminators, drift loss can be limited to $0.1 \%$ from $0.2 \%$ of the total circulating water (Perry and Green 2008). The water consumption can then be limited to $2.8 \mathrm{~m}^{3} / \mathrm{MWh}$ at $\mathrm{CoC}$ of 4 .

The overall water consumption of coal TPPs in 2030 for cumulative installed capacity of $263 \mathrm{GW}$ is also estimated at various scenarios as shown in Fig. 4. The total water consumption will increase to 7030 million $\mathrm{m}^{3}$, provided, all coal TPPs including new plants $(28 \mathrm{GW})$ operate at current average specific water consumption of $5 \mathrm{~m}^{3} / \mathrm{MWh}$ with WCT (Business As Usual (BAU) scenario). With compliance to new water standards in all TPPs, water consumption can be reduced to 5800 million $\mathrm{m}^{3}$ in 2030. Installation of ACC in all planned TPPs of $28 \mathrm{GW}$ and complying with the new water standards in existing TPPs would reduce the water consumption to 5754 million $\mathrm{m}^{3}$. This additional savings of 46 million $\mathrm{m}^{3}$ is sufficient to cater the drinking water needs of 360 million people in India at per capita consumption rate of $3.5 \mathrm{~L}$ per day.

\section{Auxiliary power consumption}

The auxiliary power consumption for wet and dry cooling towers was estimated for a $660 \mathrm{MW}$ coal TPP unit located at Nellore. The auxiliary power consumption of WCT and ACC is $0.51 \%$ and $1.30 \%$, respectively. The annual increase in auxiliary power consumption in $660 \mathrm{MW}$ coal TPP with ACC is around 34,255 MWh compared with those with WCT. With the implementation of ACC in all new coal TPPs of $28 \mathrm{GW}$, the overall annual auxiliary power consumption would go up by 1.5 TWh in 2030 .

\section{Cost of electricity generation}

Water consumption; auxiliary power consumption; and other factors like capital cost, O\&M cost, land footprint, and degradation of power plant performance for wet and dry cooling systems are quantified in terms of the cost of electricity. The cost of electricity generation for the model TPP of 660 MW with WCT located at Nellore is INR 3.63/
Fig. 3 Variation in water consumption with cycles of concentration

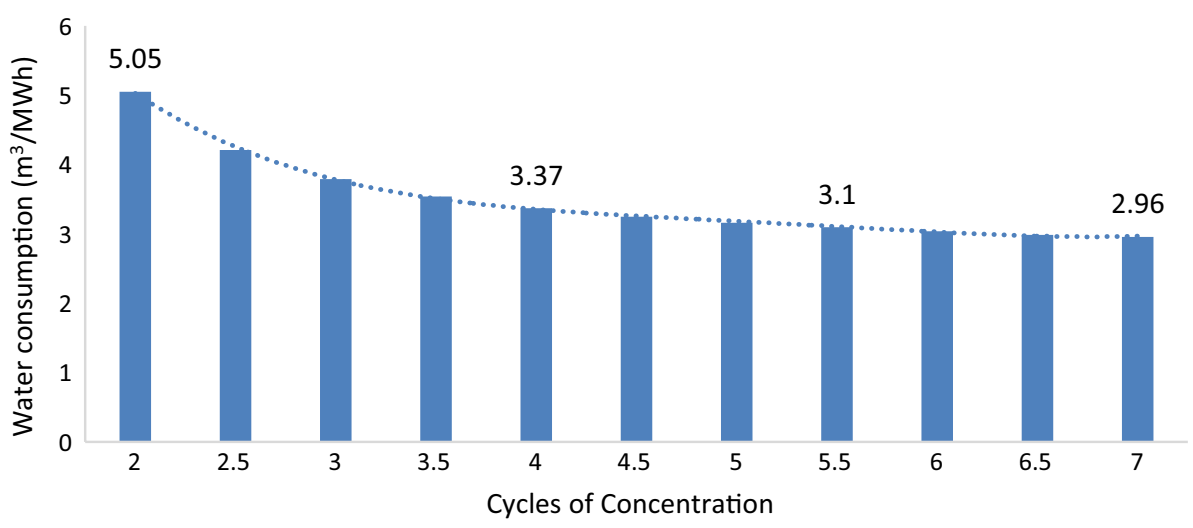

Fig. 4 Total water consumption in 2030 under various scenarios

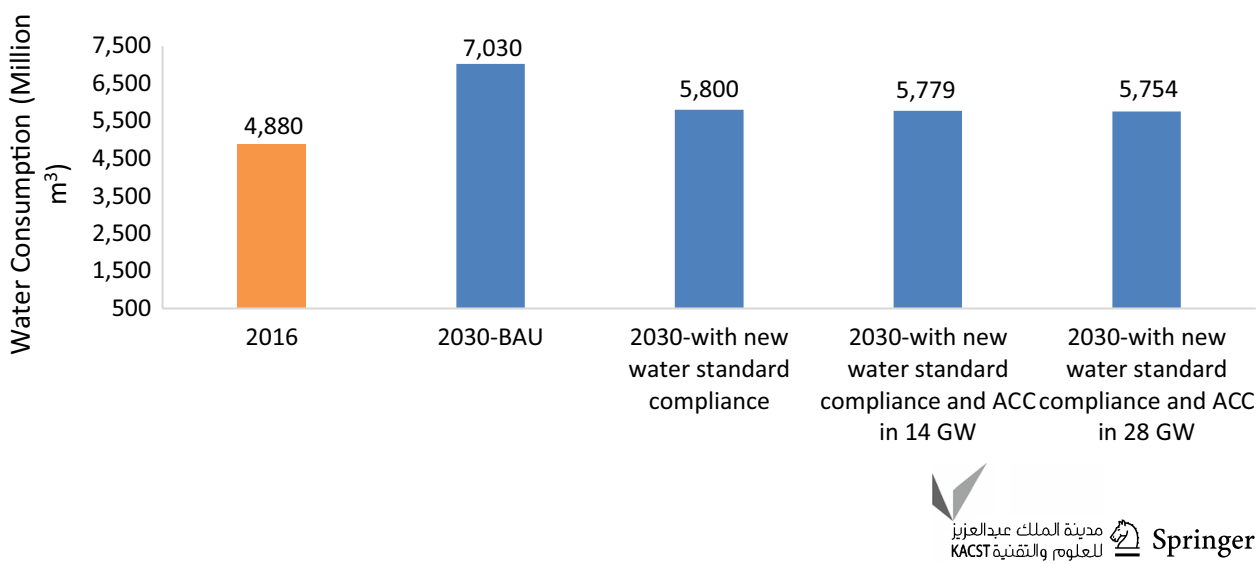


kWh (Induced draft) (5.18 US cents/kWh)-INR 3.65/kWh (5.21 US cents/kWh) (natural draft). The cost of electricity generation for the similar $660 \mathrm{MW}$ TPP with ACC would be INR $0.23-0.26 / \mathrm{kWh}$ (US cents $0.33-0.37 / \mathrm{kWh})(7-8 \%$ ) higher than TPP with WCT of induced draft and natural draft, respectively. However, the cost of electricity generation for new TPPs with ACC levelized over 25 years of useful life will be $0.17 \mathrm{INR} / \mathrm{kWh}$ (US cents $0.24 / \mathrm{kWh}$ ) less than TPPs with WCT vulnerable to 1.5 months (current average shutdown due to water scarcity) of shutdown annually.

The overall additional upfront capital cost required for ACC implementation in all new coal TPPs of $28 \mathrm{GW}$ is estimated as INR 22 thousand million (USD 314 million). This is a marginal increase of around $1.3 \%$ of the total capital cost required for the base plant construction (without cooling systems) (INR 168 thousand million) (USD 2400 million). Therefore, the additional increase in upfront cost with ACC is easily manageable.

\section{Sensitivity analysis}

The performance of the cooling system depends on ambient air conditions. Since WCT works on the principle of evaporative cooling, the auxiliary power consumption would have a strong relation with relative humidity. The relative humidity is varied between 40 and $70 \%$ at an ambient temperature of $32{ }^{\circ} \mathrm{C}$, and the auxiliary power consumption of WCT is analyzed. At a higher relative humidity, auxiliary power consumption of the mechanical draft fan will increase to achieve the required cooling due to a lowering of the mass transfer driving force (Fig. 5).

Since ACC works similar to a heat exchanger, it has a strong dependence on ambient air temperature. In our sensitivity analysis, air temperature is varied between $15^{\circ} \mathrm{C}$ (minimum temperature at power plant cluster regions) and $42{ }^{\circ} \mathrm{C}$ (maximum temperature at power plant cluster regions) at a relative humidity of $60 \%$. The auxiliary consumption of ACC varies between $0.83 \%$ at $15{ }^{\circ} \mathrm{C}$ and $2.21 \%$ at $42{ }^{\circ} \mathrm{C}$.

Sensitivity analysis of cost of electricity generation for 660 MW TPP with WCT on shutdown periods due to water shortage was also performed (Fig. 6). From the graph, we can infer that the installation of ACC in new TPPs prone to at least one month of water shortage is economical compared with WCTs. TPPs with WCT that would experience one to six months of forced shutdown due to water shortage will see an increase in their cost of electricity generation by up to $7 \%$ (INR $0.28 / \mathrm{kWh}$ ) (US cents $0.4 / \mathrm{kWh}$ )-118\% (INR 4.31/ $\mathrm{kWh}$ ) (US cents 6.15/kWh).
Fig. 5 Variation in auxiliary power consumption of WCT with relative humidity
Fig. 6 Variation in cost of electricity generation with number of months shutdown due to water shortages
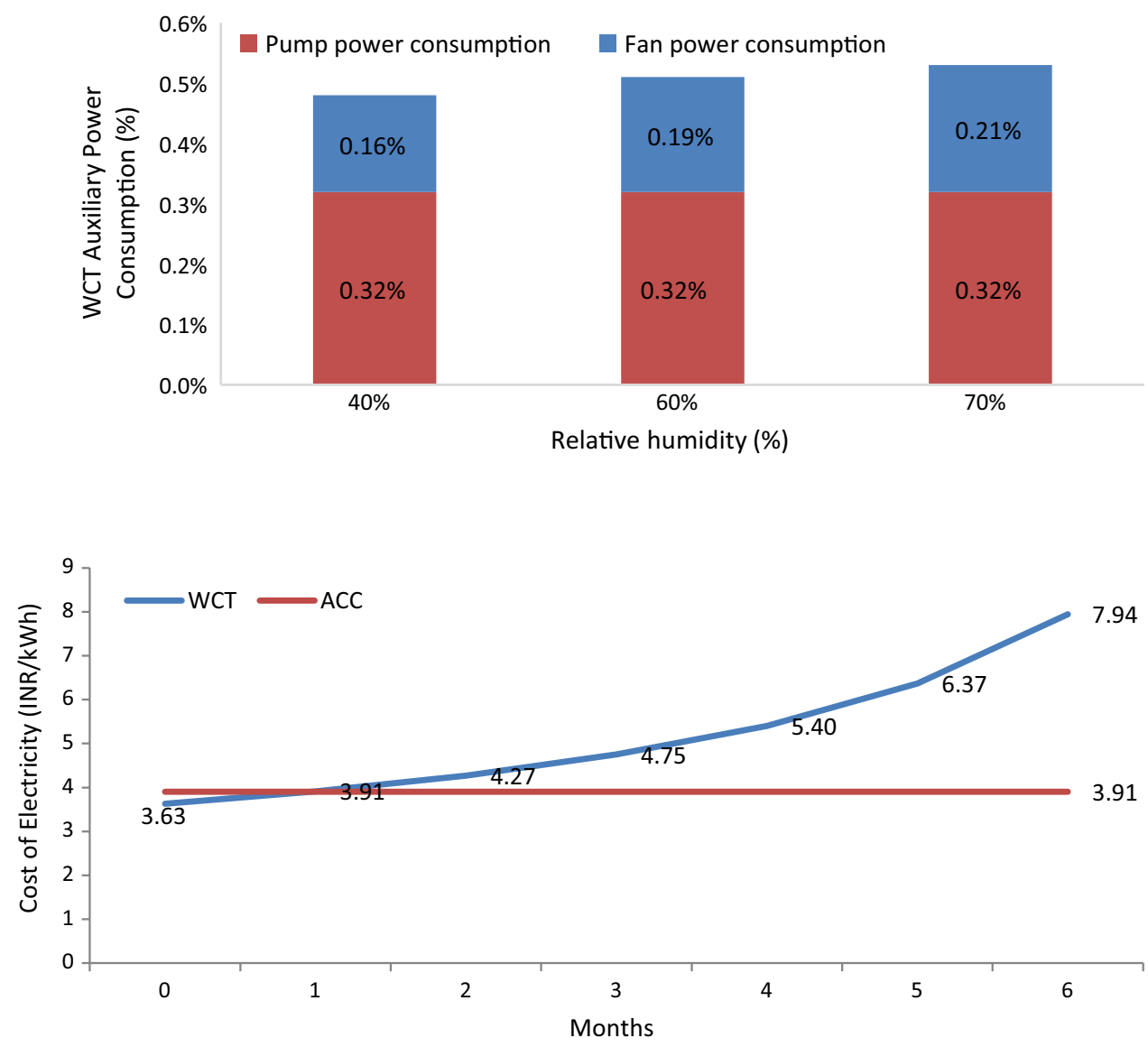
The overall electricity generation loss in new TPPs experiencing one to 6 months of water shortage-induced shutdowns would be between $14 \mathrm{TWh}$ (around INR 42 billion or USD 600 million) and 91 TWh (around INR 272 billion or USD 3.8 billion). This is around 10-65 times higher than the additional annual auxiliary consumption required for ACC operation.

\section{Conclusion}

This study analyzed the techno-economic feasibility of ACC in Indian coal TPPs at selected coal cluster regions. The critical parameters such as auxiliary power consumption, water consumption, and cost of electricity generation for a model TPP with ACC are compared with WCT systems. While ACC is bound to increase the cost of electricity generation by $7-8 \%$ owing to higher capital cost and auxiliary power consumption, the water footprint is very less compared to those TPP with WCT. In addition, ACC is more economically viable than WCT for TPPs prone to water shortages. The cost of electricity generation for a new TPP with WCT experiencing shutdown for 1 to 6 months would increase by INR $0.28 / \mathrm{kWh}$ (US cents $0.4 / \mathrm{kWh}$ ) to INR $4.31 / \mathrm{kWh}$ (US cents $6.15 / \mathrm{kWh}$ ), respectively. This accounts to a total generation loss of around 14-91 TWh annually. This makes ACC an attractive option considering the likely deficit in water supply in near future.

The current study shows that the auxiliary power consumption of ACC is strongly dependent on ambient air temperature and relative humidity. However, site-specific parameters such as the annual temperature profiles, wind speed and direction, and topography could also impact the operation of ACC. Therefore, a detailed site-specific study has to be undertaken to thoroughly evaluate the feasibility of ACC for a given plant. Ministry of Power, Government of India, could consider including a feasibility study of ACC as a part of guidelines for the detailed plant project report.

Funding No fund/grant received for this study.

\section{Compliance with ethical standards}

Conflict of interest The author declares that there is no conflict of interest.

Open Access This article is licensed under a Creative Commons Attribution 4.0 International License, which permits use, sharing, adaptation, distribution and reproduction in any medium or format, as long as you give appropriate credit to the original author(s) and the source, provide a link to the Creative Commons licence, and indicate if changes were made. The images or other third party material in this article are included in the article's Creative Commons licence, unless indicated otherwise in a credit line to the material. If material is not included in the article's Creative Commons licence and your intended use is not permitted by statutory regulation or exceeds the permitted use, you will need to obtain permission directly from the copyright holder. To view a copy of this licence, visit http://creativecommons.org/licenses/by/4.0/.

\section{References}

Abbi YP (2011) Energy audit: thermal power, combined cycle, and cogeneration plants. The Energy and Resources Institute, New Delhi

Amit N, Prajapathi P, Singh RP, Khan SA (2015) Air cooled condensers. https://www.slideshare.net/ravi0704/air-cooled-condensers. Accesssed 11 Oct 2018

Bhattacharya K (2016) Water efficiency in thermal power sector: an outline of cooling technology in India. https://cdn.cseindia.org/ userfiles/Kalyan-Bhattacharya-2.pdf. Accessed 10 Nov 2018

Burton B (2018) India's coal power plants are shutting down because they don't have enough water. In: Climate change - the new economy. http://climatechange-theneweconomy.com/indias-coal-power -plants-shutting-dont-enough-water/. Accessed 13 Mar 2019

Burton B, Fernandes A (2016) Drought hits Indian coal plants and plans. https://endcoal.org/2016/03/drought-hits-indian-coal-plant s-and-plans/. Accessed 25 Mar 2019

Carpenter AM (2015) Water availability and policies for the coal power sector. IEA Clean Coal Centre, London

CEA (2015) Annual performance review of thermal power stations for 2014-15. Central Electricity Authority, Ministry of Power, Government of India

CEA (2018) Committee on optimal energy mix in power generation on medium and long term basis. New Delhi

CEEW (2017) Implications of shared socio-economic pathways for India's long-term electricity generation and associated water demands. Council on Energy, Environment and Water, New Delhi

CERC (2014) Central electricity regulatory commission (terms and conditions of tariff) regulations, 2014. Central Electricity Regulatory Commission, New Delhi

CoalSwarm (2016) India and coal. In: SourceWatch. Center for Media and Democracy. https://www.sourcewatch.org/index.php/India and_coal. Accessed 11 Dec 2018

CSE (2014) The state of our power plants. Centre for Science and Environment, New Delhi

Dutta BK (2007) Principles of mass transfer and separation processes. PHI Learning Private Limited, New Delhi

Dutta BK (2009) Heat transfer: principle and applications. PHI Learning Private Limited, New Delhi

Engineering ToolBox (2003) Overall heat transfer coefficients for fluids-heat exchanger surface. https://www.engineeringtoolbox. com/overall-heat-transfer-coefficients-d_284.html. Accessed 20 Mar 2019

EPRI, California Energy Commission (2002) Comparison of alternate cooling technologies for california power plants economic, environmental and other tradeoffs. California Energy Commission, Palo Alto

Gao J, Zhao P, Zhang H et al (2018) Operational water withdrawal and consumption factors for electricity generation technology in China-a literature review. MDPI 10:1-15. https://doi. org/10.3390/su10041181

GPSA (2004) Air-cooled exchangers. In: GPSA engineering data book, 12th edn. Gas Processors Suppliers Association

Greenpeace International (2015) The great water grab-how the coal industry is deepening the global water crisis. http://www.green peace.org/archive-international/Global/international/publications/ climate/2016/The-Great-Water-Grab.pdf. Accessed 29 Oct 2018

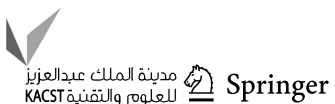


Hamon group (2018) Natural draft cooling towers. https://www.europ ages.co.uk/Natural-draft-cooling-towers/HAMON/cpid-55611 89.html. Accessed 11 Nov 2018

Manish B, Bartaria VN (2013) A review on performance analysis of air-cooled condenser under various atmospheric conditions. Int $\mathrm{J}$ Mod Eng Res (IJMER) 3:411-414

MoEFCC (2015) Notification on emission standards in coal power plants (Gazette Notification). Ministry of Environment, Forest and Climate Change, Government of India, New Delhi

Muthuraman M (2016) Reduction in power plant specific water consumption. Indian Power Stations - IPS 2016, Noida

Narayanan K (2013) A textbook of chemical engineering thermodynamics. PHI Learning Private Limited, New Delhi

Nexant, Inc (2014) Best practices manual for Indian supercritical plants

NITI Aayog (2018) Composite water management index- a tool for water management. New Delhi

Olsson E (2015) Water use in the chinese coal industry. Uppsala University, Uppsala

Paharpur (2018) Drift eliminator. http://www.paharpur.com/products/ components/drift-eliminator/. Accessed 3 Oct 2018

Perry RH, Green DW (2008) Psychrometry, evaporative cooling, and solids drying. In: Perry RH, Green DW, Maloney JO (eds) Perry's chemical engineers' handbook. McGraw-Hill, New York

Srinivasan S, Roshna N, Guttikunda SK et al (2018) Benefit cost analysis of emission standards for coal based thermal power plants in India. Center for Study of Science, Technology and Policy, Bangalore

Tenaska Trailblazer Partners, LLC (2012) Front end engineering and design study report for carbon dioxide capture
Tianyi L, Krishnan D, Sen S (2018) Parched power: water demands, risks and opportunities for India's power sector. World Resource Institute, Washington DC

Timeanddate.com (2018) Climate and weather averages in Nellore, Andhra Pradesh, India. https://www.timeanddate.com/weather/ india/nellore/climate. Accessed 2 Nov 2018

WaterAid (2018) The water gap-the state of the world's water 2018

World Weather Online (2018) World weather online. https://www. worldweatheronline.com/. Accessed 18 Oct 2018

Xinxin Z, Junguo L, Yu T et al (2017) China's coal-fired power plants impose pressure on water resources. J Clean Prod. https://doi. org/10.1016/j.jclepro.2017.04.040

Zhai H, Rubin ES (2010) Performance and cost of wet and dry cooling systems for pulverized coal power plants with and without carbon capture and storage. Energy Policy 38:5653-5660. https ://doi.org/10.1016/j.enpol.2010.05.013

Zhai H, Rubin ES (2016) A techno-economic assessment of hybrid cooling systems for coal- and natural-gas-fired power plants with and without carbon capture and storage. Environ Sci Technol 50:4127-4134. https://doi.org/10.1021/acs.est.6b00008

Publisher's Note Springer Nature remains neutral with regard to jurisdictional claims in published maps and institutional affiliations. 